\title{
TAXONOMIC AND COMPOSITIONAL DIFFERENCES OF GROUND-DWELLING ARTHROPODS IN RIPARIAN HABITATS IN GLEN CANYON, ARIZONA, USA
}

\author{
Barbara E. Ralston ${ }^{1,2}$, Neil S. Cobb ${ }^{3}$, Sandra L. Brantley ${ }^{4}$, Jacob Higgins ${ }^{3}$ and Charles B. Yackulic ${ }^{1}$
}

Aвstract.-The disturbance history, plant species composition, productivity, and structural complexity of a site can exert bottom-up controls on arthropod diversity, abundance, and trophic structure. Regulation alters the hydrology and disturbance regimes of rivers and affects riparian habitats by changing plant quality parameters. Fifty years of regulation along the Colorado River downstream of Glen Canyon Dam has created a no-analog, postdam "lower" riparian zone close to the water's edge that includes tamarisk (Tamarix sp.), a nonnative riparian shrub. At the same time, the predam "upper" facultative riparian zone has persisted several meters above the current flood stage. In summer 2009, we used pitfall traps within these 2 riparian zones that differ in plant composition, productivity, and disturbance frequency to test for differences in arthropod community (Hymenoptera, Arachnida, and Coleoptera) structure. Arthropod community structure differed substantially between the 2 zones. Arthropod abundance and species richness was highest in the predam upper riparian zone, even though there was a greater amount of standing plant biomass in the postdam lower riparian zone. Omnivore abundance was proportionately greater in the upper riparian zone and was associated with lower estimated productivity values. Predators and detritivores were proportionately greater in the postdam lower riparian zone. In this case, river regulation may create habitats that support species of spiders and carabid beetles, but few other species that are exclusive to this zone. The combined richness found in both zones suggests a small increase in total richness and functional diversity for the Glen Canyon reach of the Colorado River.

Resumen.—La historia de perturbaciones, la composición de las especies vegetales, la productividad y la complejidad estructural de un sitio pueden ejercer controles ascendentes sobre la diversidad de artrópodos, su abundancia y su estructura trófica. Los ríos controlados alteran los regímenes hidrológicos y de equilibrio de los ríos y afectan los hábitats ribereños al modificarse los parámetros de calidad de la vegetación. Cincuenta años de regulación de la presa Glen Canyon del descendente Río Colorado, ha creado una zona ribereña "inferior", no-análoga (posterior a la presa) cercana a la orilla del agua en la que se observan Tamarix sp., un arbusto ribereño exótico. Al mismo tiempo, la zona ribereña facultativa "superior" (previa a la presa) ha subsistido varios metros por encima de la actual fase de inundación. En el verano del 2009, utilizamos trampas dentro de estas dos zonas ribereñas que diferían en cuanto a su composición vegetal, su productividad y su frecuencia de interrupción, para evaluar las diferencias en la estructura de las comunidades de artrópodos (Hymenoptera, Arachnida y Coleoptera), la cual difería sustancialmente entre las dos zonas. La abundancia de artrópodos y la riqueza de especies fueron más altas en la zona superior, previa a la presa, a pesar de que había una mayor cantidad de biomasa vegetal permanente en la zona inferior de la ribera, posterior a la presa. La abundancia omnívora fue proporcionalmente mayor en la zona ribereña superior y resultó relacionada a menores valores estimados de productividad. La abundancia de los depredadores y los detritívoros fue proporcionalmente mayor en la zona baja de la ribera, posterior a la presa. En este caso, la regulación del río puede crear hábitats que albergan especies de arañas y de escarabajos carábidos, pero pocas otras especies exclusivas de esta zona. La riqueza combinada encontrada en ambas zonas sugiere un pequeño aumento en la riqueza total y en la diversidad funcional de la extensión del Glen Canyon del Río Colorado.

The presence and quality (e.g., productivity, structure, native or nonnative status) of vegetation affects arthropod communities. High plant diversity supports a diverse arthropod community (Strong et al. 1984, Siemann et al. 1998). Similarly, high plant productivity can support greater abundances and diversity of arthropod species, though this is not consistent among habitats (Siemann 1998, Schaffers et al. 2008). In contrast, the presence and dominance of nonnative plant species can reduce arthropod diversity by affecting plant quality parameters due to either reduced plant species diversity or reduced plant structural complexity (Herrera and Dudley 2003, Topp et al. 2008, Maceda-Veiga et al. 2016). Mechanisms that promote colonization of nonnative plant species include event-level processes, such as disturbance, occupation of empty niches, allelopathy associated with the nonnative species, and lack of herbivore enemies (Porras-Alfaro et al. 2011). Collectively these

${ }^{1}$ U.S. Geological Survey, Southwest Biological Science Center, Flagstaff, AZ 86001

${ }^{2}$ Corresponding author. Present address: U.S. Geological Survey, Office of Science Quality and Integrity, Flagstaff, AZ 86001. E-mail: bralston@usgs.gov

${ }^{3}$ Merriam-Powell Center for Environmental Research, Northern Arizona University, Flagstaff, AZ 86011

${ }^{4}$ Museum of Southwestern Biology, University of New Mexico, Albuquerque, NM 87131. 
mechanisms can interact to create a heterogeneous environment composed of variable plant quality and diversity that may also exert bottom-up controls on arthropod diversity and abundance (Perner et al. 2005, Woodcock et al. 2010). Because ground-dwelling arthropod communities are dominated by nonherbivorous species (i.e., detritivores, omnivores, predators), the impact of dominant riparian vegetation will likely be indirect through structural changes in the habitat or direct through changes in plant litter (Tuttle et al. 2009, Maceda-Veiga et al. 2016).

Riparian areas in the southwestern United States support higher plant and animal diversity than adjacent upland habitats (Knopf et al. 1988, Stromberg et al. 1991) and affect overall landscape diversity (Sabo et al. 2005). In unregulated reaches, these habitats are subject to disturbance due to their adjacency to a river's channel and as a result are heterogeneous in composition and display mosaics of plant assemblages that vary in time since disturbance. In regulated reaches, difference in the disturbance interval following flow regulation (flood frequency, magnitude, and duration) can result in and support novel riparian or wetland habitats that were either absent or rare prior to regulation (Stevens et al. 1995, Johnson 2002). As a result of altered hydrology, many riparian habitats in regulated reaches are now dominated by nonnative riparian shrubs (Stromberg 2001, Friedman et al. 2005, Birkin and Cooper 2006). Riparian habitats dominated by nonnative plants and frequently characterized by lowered plant diversity often offer reduced habitat quality for arthropods, potentially leading to diminished diversity and abundance (Gerber et al. 2008, Tuttle et al. 2009, Litt et al. 2014, Nguyen et al. 2016).

How arthropods respond to novel or "created" riparian and marsh habitats is little studied. We might expect that negative responses associated with arthropod diversity may occur where nonnative plant species have replaced previous native vegetation stands. On the other hand, when novel riparian or marsh habitats colonize areas where habitat (i.e., vegetation) was previously absent or sparse, we might expect landscape-scale arthropod diversity and abundance to increase because of the increased opportunities for species to occupy open niches, or habitats that differ from those dominated by native, relict riparian species. For these novel habitats, we might expect patterns of response to be similar to arthropod colonization on islands, on agricultural field edges, or in manipulated field experiments (Siemann et al. 1998, Gillespie and Roderick 2002), where arthropod diversity increases with increasing plant diversity. But plant species composition (e.g., plant quality) may limit arthropod diversity. For example, plant-dwelling arthropod diversity is often lower in habitats dominated by nonnative plant species compared with similar habitats dominated by native plant species (Litt et al. 2014). Similarly, in several studies, ground-dwelling arthropod diversity in riparian habitats that were dominated by nonnative plant species (e.g., Tamarix sp., saltcedar, or Arundo donax L.) was unaffected or lower compared to similar habitats where native plants dominated (Ellis et al. 2000, Herrera and Dudley 2003, Topp et al. 2008). In a woodland setting, Nguyen et al. (2016) also found that arthropod species richness declined as a nonnative dominant olive (Olea europaea ssp. cuspidata [Wall. ex G. Don] Cif.) tree community matured. Arthropod diversity may differentially respond to the type of plant diversity (native versus nonnative), rather than greater plant diversity, in general (Litt et al. 2014, van Hengstum et al. 2014).

The creation of new habitat, or the shoreward expansion of riparian plant species into unvegetated substrate in response to river regulation, presents vegetation structure that differs from the existing vegetation either by time since disturbance or by species composition and can affect the associated trophic community structure. The banks of the Colorado River downstream of Glen Canyon Dam provide opportunities to assess difference in ground-dwelling arthropod richness and trophic community structure among 2 riparian habitats that exist contemporaneously along the river's bank and that are subject to different disturbance intervals (Figs. 1, 2). The 2 habitats are (1) a relictual, predam "upper" riparian habitat or zone (URZ), located several meters above the river's baseflow, and last disturbed by flood waters in 1983 (Topping et al. 2003; Fig. 2) and (2) a novel, postdam "lower" riparian and fluvial marsh community or zone (LRZ) existing closer to the water's edge (Carothers and Brown 1991, Stevens et al. 


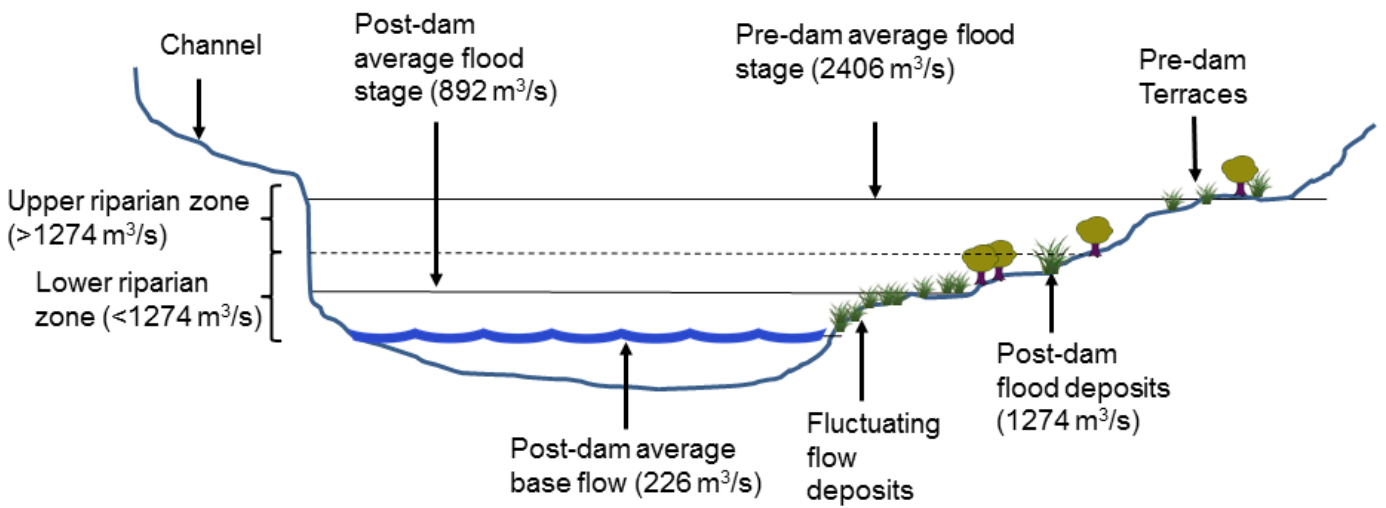

Fig. 1. Diagram of a cross section of the river channel identifying the pre- and postdam average flood stage and the associated upper and lower riparian zone locations. Average base flow since regulation $\left(226 \mathrm{~m}^{3} / \mathrm{s}\right)$ and locations of postdam flood deposits are also illustrated. The frequency of disturbance by floods $>1274 \mathrm{~m}^{3} / \mathrm{s} \mathrm{has} \mathrm{diminished} \mathrm{since}$ regulation began, resulting in a disconnected relict upper riparian zone and a newer lower riparian zone. The latter is subject to daily inundation at lower river stages, and the former is affected more by local precipitation than by dam operations. Vegetation in the lower riparian zone is denser in comparison to the upper riparian zone.

1995, Sankey et al. 2015), subject to daily and annual disturbance.

The 2 riparian zones present a unique setting to explore hypotheses about arthropod community structure, specifically about the effects of disturbance frequency and plant quality on ground-dwelling arthropod species richness and abundance. Understanding the structure of relict and novel communities also provides a baseline to understand how riparian arthropod communities may respond to changes in climate, including reduced water supplies and corresponding reduced flows and disturbance frequency (Seager et al. 2012). We asked the following questions: (1) How do plant compositional differences between relict (URZ) and postregulation (LRZ) riparian habitats affect species richness and abundance of ground-dwelling arthropods? Based on other studies, we predict that species richness would be greater in the URZ. (2) Do feeding groups differ among habitats? Plant species and cover differ among habitats, and assuming that structural complexity is greater with increasing plant diversity, we would also predict that the URZ would support a greater diversity of feeding guilds. Three groups of ground-dwelling arthropods (Hymenoptera, Arachnida, and Coleoptera) were the focus of this analysis because they encompass the vast majority of diversity and abundance in grounddwelling arthropods and are abundant enough to allow us to address the questions posed.

\section{Methods}

\section{Study Area}

Sampling for ground-dwelling arthropods occurred from June to August 2009 at 3 sites along a 25-km stretch of the Colorado River, immediately downstream of Glen Canyon Dam in Glen Canyon National Recreation Area (Fig. 3, Table 1). The number of sites sampled was constrained by the time required in a single day to collect and deploy pitfall traps along the river stretch. The sites were well separated from each other and avoided an edge effect from being too near the dam itself or too near Lees Ferry, which is considerably affected by people. The site numbering proceeded from Glen Canyon Dam to Lees Ferry. This river segment is the remnant of Glen Canyon, which extends $321 \mathrm{~km}$ upstream of Lees Ferry. Lake Powell, the reservoir impounded by Glen Canyon Dam, floods the rest of Glen Canyon. Tall canyon walls composed of Navajo Sandstone and channel margin deposits that vary between 30 and 90 m wide (Grams et al. 2007) characterize the shoreline of Glen Canyon. The channel is incised and meanders (Harden 1990).

The presence and operations of Glen Canyon Dam changed the magnitude and timing of fluvial disturbance and resulted in different habitat quality parameters between the 2 riparian zones. Following regulation, the URZ is associated with elevations at or above 

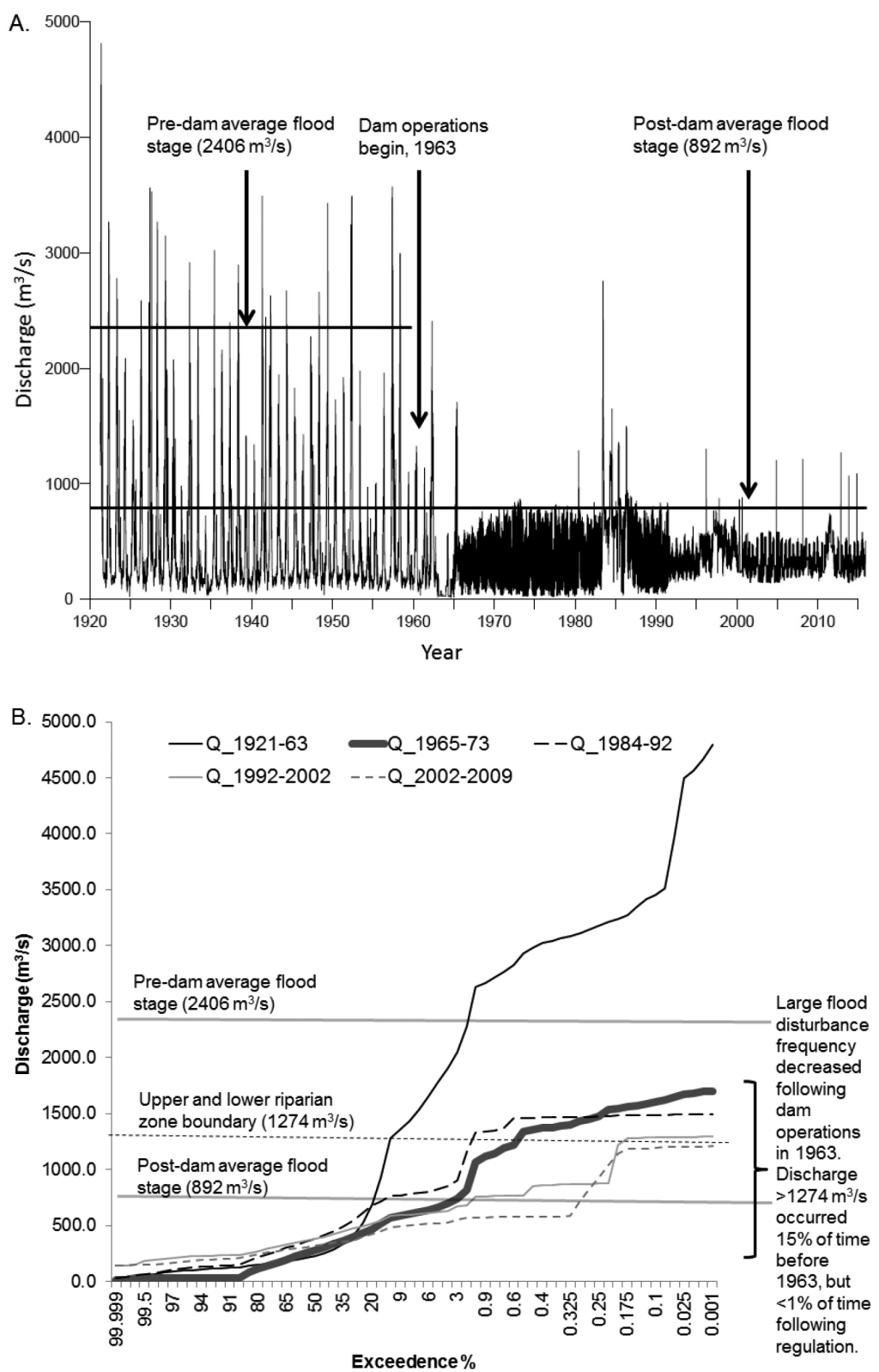

Fig. 2. Hydrograph (A) and exceedance percentage (B) for the Colorado River as recorded at Lees Ferry, Arizona, from 1921 to present. The hydrograph (A) identifies the pre- and postdam average flood stages $\left(2406 \mathrm{~m}^{3} / \mathrm{s}\right.$ and $892 \mathrm{~m}^{3} / \mathrm{s}$, respectively) and the year Glen Canyon Dam became operational (1963). The exceedance graph (B) illustrates the percent of time that discharge $(\mathrm{Q})$ was exceeded for blocks of time that represent large changes in the hydrograph of the Colorado River. The graph illustrates that the frequency of disturbance by floods $>1247 \mathrm{~m}^{3} / \mathrm{s}$, an upper boundary of the lower riparian zone, has diminished since regulation began.

a flood stage of $1274 \mathrm{~m}^{3} / \mathrm{s}$ (Figs. 1, 2), was last inundated in 1983 (Topping et al. 2003), and is affected more by local precipitation events than dam operations (Sankey et al. 2015). In the LRZ, which is below stage $1274 \mathrm{~m}^{3} / \mathrm{s}$, intermittent flood events rework sediment deposits (Grams et al. 2015) but tend to temporarily bury rather than remove vegetation (Kearsley and Ayers 1999), resulting in denser plant cover compared with the URZ. 


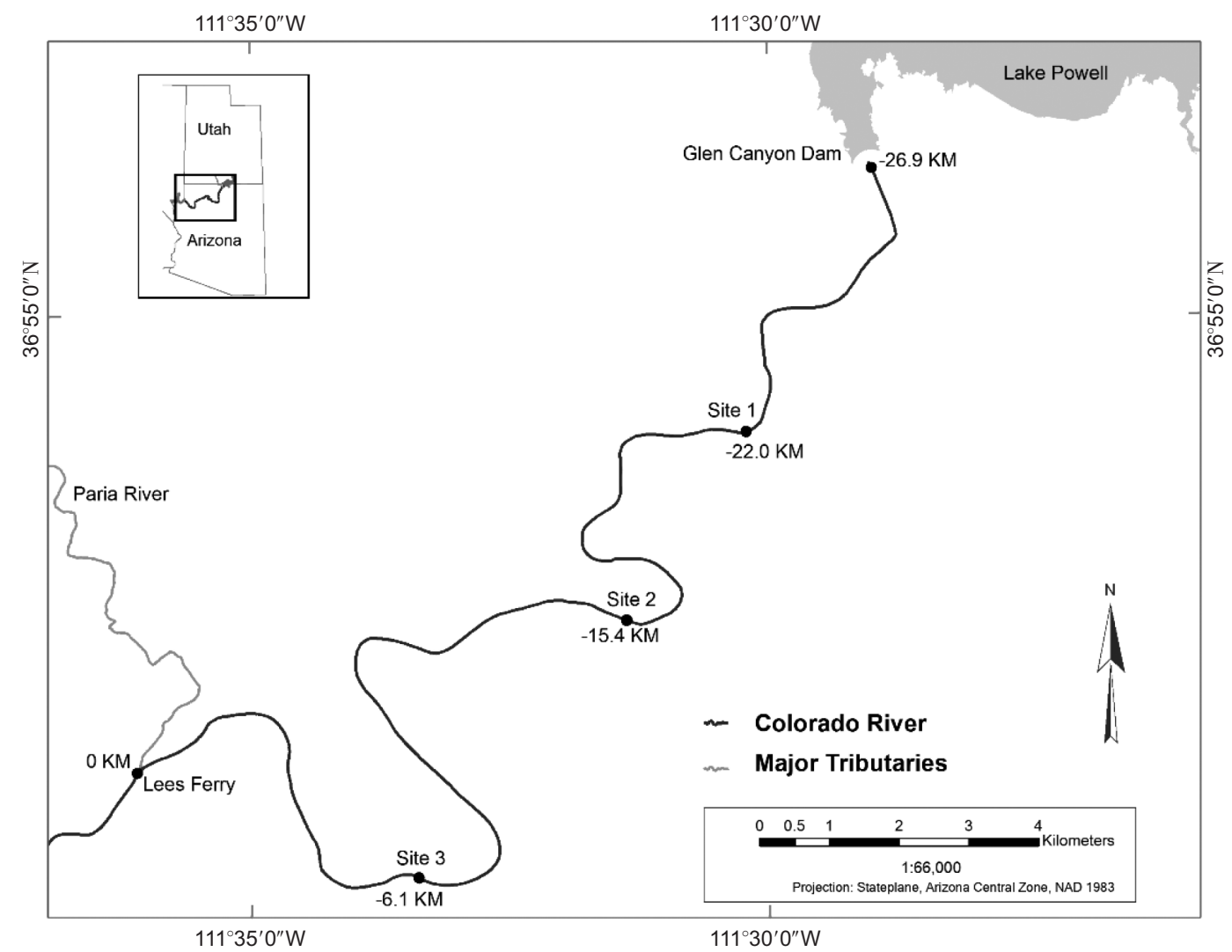

Fig. 3. Map of the Colorado River between Glen Canyon Dam and Lees Ferry, Arizona, with the 3 pitfall trap sampling site locations noted in river kilometers. By convention, river kilometers start from Lees Ferry (RK 0). River kilometers downstream from Lees Ferry are positive, and those upstream are negative.

Prior to river regulation, the mean annual flood volume of $2406 \mathrm{~m}^{3} / \mathrm{s}$ (Topping et al. 2003) limited the persistence of obligate riparian and wetland plants along the shoreline and left shorelines bare (Clover and Jotter 1944, Howard and Dolan 1981). Instead, vegetation on the banks consisted of woody facultative riparian vegetation and desert shrubs largely restricted to the flood terraces, located several meters above the river's base flow (Hereford et al. 2000, Grams et al. 2007). Plants found in the URZ include tamarisk (Tamarix sp.), netleaf hackberry (Celtis laevigata Willd. var. reticulata [Torr.] L.D. Benson), desert olive (Forestiera pubescens Nutt. var pubescens), Sonoran scrub oak (Quercus turbinella Greene), seepwillow (Baccharis emoryi A. Gray), Apache plume (Fallugia paradoxa [D. Don] Endl. ex Torr.), four-wing saltbush (Atriplex canescens [Pursh] Nutt.), rabbitbrush (Ericameria nauseosa [Pall. ex Pursh] G.L. Nesom \& Baird), and snakeweed (Gutierrezia microcephala [DC.] A. Gray).

That river regulation changed the physical and biological character of the Colorado River and its shoreline downstream of Glen Canyon Dam is well documented (Howard and Dolan 1981, Carothers and Brown 1991, Stevens et al. 1995, Hazel et al. 2006, Kennedy et al. 2014). With respect to hydrology and sediment transport, closure of Glen Canyon Dam in 1963 reduced the mean annual flood magnitude by $63 \%$ (Fig. 2A), reduced sediment loads in Glen Canyon by $99 \%$, and caused sediment deposits along the shore to become coarser (Topping et al. 2000). The frequency of flooding changed from an annual event to daily inundation at discharge $<500 \mathrm{~m}^{3} / \mathrm{s}$, with $\leq 1 \%$ of discharges greater than $1274 \mathrm{~m}^{3} / \mathrm{s}$ (Fig. 2B). Since 1996, discharges from Glen Canyon Dam have not exceeded $1274 \mathrm{~m}^{3} / \mathrm{s}$ (Schmidt and Grams 2011). The channel in Glen Canyon has 


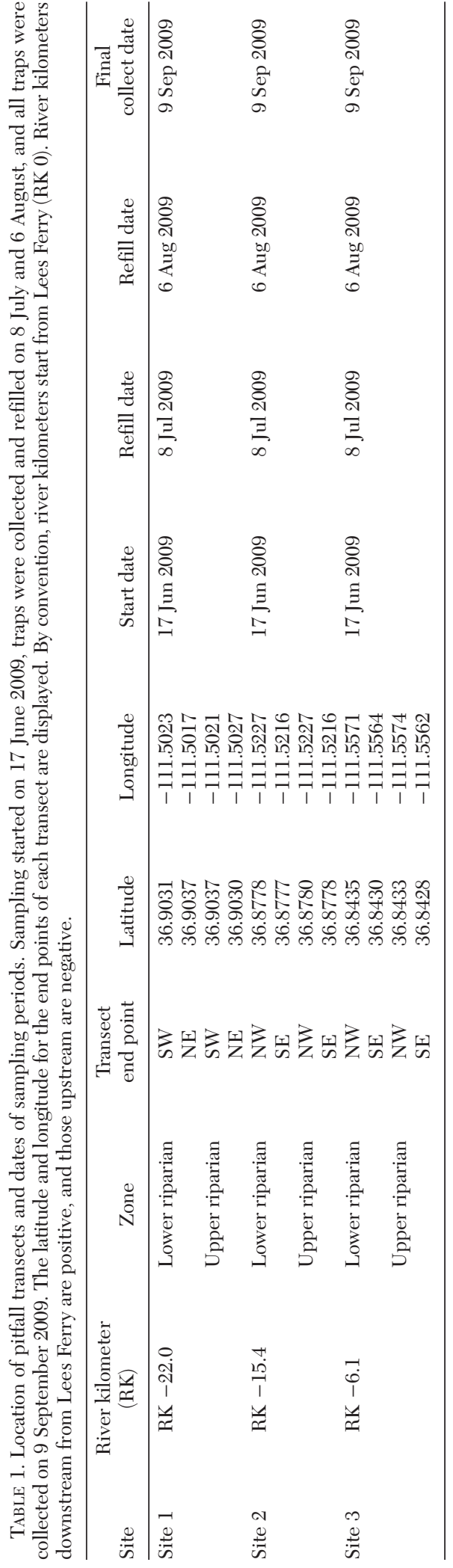

become further incised since regulation (Grams et al. 2007) and has further disconnected the predam terraces and URZ from the river's hydrology.

Following the closure of Glen Canyon Dam in 1963, reduced flood magnitude exposed shorelines to plant colonization, and the largely bare talus slopes and sandbars along the river became vegetated by 1973 (Webb 1996, Sankey et al. 2015). Tamarisk became the dominant overstory plant (Turner and Karpiscak 1980, Stevens et al. 1995, Mortenson et al. 2012), and other obligate riparian shrubs such as seepwillow (Baccharis salicifolia [Ruiz \& Pav.] Pers. and B. emoryi A. Gray) and coyote willow (Salix exigua Nutt.) established along the channel. Other plant species found in the LRZ include arrowweed (Pluchea sericea [Nutt.] Coville), sweet clover (Melilotus officinalis [L.] Lam), red brome (Bromus rubens L.), and common reed (Phragmites australis [Cav.] Trin. ex Steud). Since 1996, restrictions on the allowable daily maximum fluctuating discharge $\left(707 \mathrm{~m}^{3} / \mathrm{s}\right)$ and daily range $\left(226 \mathrm{~m}^{3} / \mathrm{s}\right)$ associated with the record of decision for Glen Canyon Dam operations (USDI 1996) further diminished the annual peak discharge. In fact, annual peak discharge has been at or below 566 $\mathrm{m}^{3} / \mathrm{s}$ since 1992 (Topping et al. 2003). Corresponding with reduced peak discharge, woody riparian vegetation cover in the $L R Z$ is greatest at or below $849 \mathrm{~m}^{3} / \mathrm{s}$ (Sankey et al. 2015).

Physical processes related to regulation have altered the substrate along the channel, further differentiating these habitats. The substrate in the LRZ is coarser with fewer silt and clay particles, while the URZ is associated with historic fine-grained fluvial deposits (Topping et al. 2005). Aboveground litter production values between the riparian zones differ by more than $250 \%$ due to the different plant species and associated cover found within each zone. Production is greater in the LRZ where tamarisk and wetland species cover is greater than in the URZ (Kennedy and Ralston 2012). The litter production estimates for the URZ average $76.5 \mathrm{~g}$ ash-free dry mass $(\mathrm{AFDM}) / \mathrm{m}^{2}$ per year. The mean litter production estimate for the LRZ in which tamarisk dominates is $299 \mathrm{~g} \mathrm{AFDM} / \mathrm{m}^{2}$ per year. Both substrate and associated plant composition resulting from historic and presentday fluvial processes affect associated biotic assemblages found along regulated rivers 
TABLE 2. Habitat description, estimated litter production, and calculated vegetated cover values for each habitat sampled.

\begin{tabular}{|c|c|c|c|c|}
\hline Habitat & $\begin{array}{l}\text { Habitat description } \\
\text { (species encountered } \\
\text { along transects) }\end{array}$ & $\begin{array}{c}\text { Estimated mean } \\
\text { annual litter production } \\
\left(95 \% \mathrm{CI} \mathrm{g} / \mathrm{m}^{2} \text { per year }\right)^{\mathrm{a}}\end{array}$ & $\begin{array}{l}\text { Substrate } \\
\text { description }\end{array}$ & $\begin{array}{l}\text { Percent cover } \\
(\text { mean } \pm \mathrm{SE})\end{array}$ \\
\hline $\begin{array}{l}\text { UPPER RIPARIAN } \\
\text { Semidesert scrub/ } \\
\text { facultative riparian } \\
\text { vegetation }\end{array}$ & $\begin{array}{l}\text { High number of desert } \\
\quad \text { shrub species } \\
\text { Acacia greggii } \\
\text { Gutierrezia sarothrae } \\
\text { Ericameria nauseosa } \\
\text { Pluchea sericea } \\
\text { Opuntia sp. } \\
\text { Atriplex canescens } \\
\text { Sporobolus cryptandrus } \\
\text { Stanleya pinnata }\end{array}$ & $76.5(9-213)$ & $\begin{array}{l}\text { Predam flood terraces } \\
\text { Fine silts and sand to } \\
\text { a mix of sand, } \\
\text { gravels, and } \\
\text { boulders } \\
\text { Decaying tree stumps } \\
\text { (tamarisk) }\end{array}$ & $\begin{array}{l}34 \% \pm 19 \% \text {, low stem } \\
\text { density, as is typical } \\
\text { of semidesert shrubs }{ }^{b}\end{array}$ \\
\hline $\begin{array}{l}\text { LOWER RIPARIAN } \\
\text { Tamarisk dominant } \\
\text { vegetation }\end{array}$ & $\begin{array}{l}\text { Low number of woody } \\
\quad \text { riparian species } \\
\text { Tamarix sp. } \\
\text { Baccharis emoryi } \\
\text { Salix exigua } \\
\text { Elymus canadensis }\end{array}$ & $299(180-418)$ & $\begin{array}{l}\text { Sand intermixed } \\
\text { with cobbles and } \\
\text { boulders and } \\
\text { driftwood piles }\end{array}$ & $\begin{array}{l}68 \% \pm 23 \% \text {, high } \\
\text { stem density as } \\
\text { is typical with } \\
\text { mid-aged } \\
\text { tamarisk stands, c }\end{array}$ \\
\hline
\end{tabular}

aFrom Kennedy and Ralston (2012)

bBagstad et al. (2006)

'Stevens et al. (1995)

(Greenwood et al. 2004, Durst et al. 2008, Rood et al. 2009).

\section{Field Sampling and Processing}

Sampling for ground-dwelling arthropods using pitfall traps occurred continuously between 17 June and 9 September 2009 (Table 1). Although pitfall trapping is a selective sampling method, and the probability of capture may reflect species activity more than abundance (Leather 2005), it is one of the most commonly used single methods for comparing ground-dwelling arthropod community differences among habitats or treatments. At each site, lines of pitfall traps were placed in both URZ and LRZ habitats.

Transects were composed of 10 pitfall traps approximately $10 \mathrm{~m}$ apart in a line parallel with the river in both zones. The LRZ trapline was positioned above the $707 \mathrm{~m}^{3} / \mathrm{s}$ stage and the URZ trapline was positioned above the postdam flood stage $\left(1274 \mathrm{~m}^{3} / \mathrm{s}\right)$ on flood terraces that are separated from LRZ by steep cutbanks. The linear distance between LRZ and URZ trap lines averaged $27.5 \mathrm{~m}, 15 \mathrm{~m}$, and $25.5 \mathrm{~m}$ for sites 1,2 , and 3, respectively. The pitfall consisted of a 32-mm-diameter $\times$ 200-mm-long borosilicate glass test tube placed inside a $25-\mathrm{cm}$-long PVC sleeve and buried in the sand. Covering each trap was a $6 \times 7.5-\mathrm{cm}$ PVC tube segment cut in half and secured with medium gage wire to prevent disturbance from rain or animals but provide access to arthropods. A 5-cm-wide soil auger created a hole for placing pitfall traps. To ensure adequate soil depth to hold a pitfall trap, a rebar was inserted into the ground at the potential trap site to determine the first suitable site within $1 \mathrm{~m}$ of the designated location. Each test tube was half-filled with propylene glycol to preserve the arthropods (Higgins et al. 2014). Test tube collection and replacement at traps occurred every 21 to $33 \mathrm{~d}$ for a total of 3 times at each site (Table 1). Although temporarily closing traps for a few days following installment and prior to sampling is warranted (Digweed 1995), traps were not closed prior to sampling due to their remote locations. Traps containing vertebrates (e.g., lizards, mice) were not included in the analysis to avoid the sample bias of traps disproportionately attracting some species. Perennial plant species associated with each transect were noted (Table 2).

We also calculated mean percent cover of woody vegetation for both zones using 2009 aerial imagery (Davis 2013). Polygons that were approximately $5 \mathrm{~m}$ on either side of the transect line and the distance of each transect were digitized using $\operatorname{ArcGIS}^{\circledR}$ (ESRI 2013). A total vegetation mask was clipped to the polygons and then intersected to determine 
the total vegetated area within each polygon. Percent total vegetation cover was determined by dividing vegetated area by total polygon area. The vegetated areas from all sites were used to calculate the mean and standard error of percent cover for both zones (Table 2).

Sample processing of 3 target groups occurred in labs at Northern Arizona University (orders Coleoptera and Hymenoptera, mostly ants) and the University of New Mexico (class Arachnida, mostly spiders). A permanent reference collection resides at the Colorado Plateau Museum of Arthropod Biodiversity at Northern Arizona University, with duplicate spiders stored at the University of New Mexico. All other arthropod orders that were collected, besides the 3 target groups, reside at Northern Arizona University for future processing. When possible, all samples were identified to species; otherwise, we categorized the specimens into morphospecies, which we presumed to be separate species, except in the case of immature specimens in Arachnida. When possible, we matched immature and adult stages of spiders in order to identify them.

Ground-dwelling arthropod communities are characterized by a paucity of herbivores and an abundance of predators and scavengers. We categorized each species into one of 4 feeding guilds (omnivores, detritivores, predators, and herbivores) based on published characteristics reported at the level of genus or family (Larochelle and Larivière 2003, Triplehorn and Johnson 2005). Although feeding habits of many species of ground-dwelling arthropods are not known, genera and families typically share the same generalized feeding habits. It is likely that several species exhibit more than one type of feeding; for example, many predatory insects will also occasionally feed on other dead insects. Omnivores in this study consisted of ants, whose diets include seeds, other arthropods, honeydew, and other plant and animal material. The only exception was Neivamyrmex, which is typical of other army ants and is considered a predator. Tenebrionid beetles comprised detritivores, as most species feed as scavengers and to a lesser degree on plants. Herbivores primarily consisted of scarab leaf beetles. The majority of these species spend most of their life cycle as larvae feeding on roots, and the adults are likely collected in pitfall traps during egg laying.

\section{Data Analysis}

We used indicator species analysis with a Monte Carlo method and test of significance (Dufrêne and Legendre 1997) to determine if specific arthropod taxa were associated with a particular riparian habitat. This procedure was performed in PC-ORD $5.10^{\circ}$ (McCune and Mefford 1999) using the complete arthropod community data set for each collection date and for each location using a date-summary data set. The group variable was riparian zone (URZ and LRZ). The indicator analysis was run using the default randomize settings in PC-ORD of 1000 runs. The results were organized by indicator value for each group variable.

Total species richness, total abundance, and the abundance within groups based either on taxonomy or feeding guilds were analyzed using generalized linear mixed models (GLMM) with a Poisson error distribution (because all these data are count data) and a log link using the lme4 package in $\mathrm{R}$ (version x64 2.14.2; R Core Team 2014). Data from individual traps were analyzed, and we included random effects for locations, dates, and traps to account for the potential for traps within a location to be nonindependent (i.e., to account for potential pseudoreplication), or for data in different months to be nonindependent (Bolker et al. 2009). Taxonomic groups considered were Hymenoptera, Arachnida, and Coleoptera. Feeding guilds considered were detritivores/herbivores, predators/parasites, and omnivores. Herbivores and parasites were both extremely rare and thus were grouped with the most similar guild. We determined whether these community measures varied between riparian zones by comparing Akaike information criterion (AIC) values from a model that included riparian zone as a categorical fixed predictor to a model that included only a single intercept (i.e., a null model where species richness, total abundance, and the abundance of various subgroups did not vary between vegetation types). AIC values are based on the fit of a model to data (i.e., the negative log-likelihood), but also penalize for complexity (i.e., extra parameters).

To complement analyses of abundance in groups based on taxonomic or feeding guilds, we also analyzed the proportion of different feeding guilds and the proportion of different taxonomic groups. Proportions 
were analyzed by determining the maximum likelihood estimates and associated AIC values for 2 models that considered different forms for the matrix of parameters, $p$, in a multinomial model whose likelihood is given by the following equation:

$$
f\left(y_{i, j} \mid n_{j}, p_{i, j}\right)=\left(\begin{array}{c}
n_{j} \\
y_{i, j}
\end{array}\right) p_{1, j}^{y_{1, j}} p_{2, j}^{y_{2, j}} p_{3, j}^{y_{3, j}},
$$

where $y_{i, j}$ is the abundance of guild $i$ or taxonomic group $i$ in vegetation type $j, n_{j}$ is the total insect abundance in vegetation type $j$, and $p_{3, j}=1-\sum_{i=1}^{2} p_{i, j}$ (i.e., only 2 of 3 cell probabilities were estimated for each vegetation type since the 3 cell probabilities must sum to 1 ). The 2 models we considered differed in whether proportions were constant across vegetation types (i.e., $p_{i, 1}=p_{i, 2}$ for all $i$ so that only 2 parameters were estimated) or were allowed to vary between vegetation types (such that 4 parameters were estimated). We did this independently for taxonomic groups and feeding guilds. Maximum likelihood estimates were obtained in $\mathrm{R}$ (version x64 2.14.2; $\mathrm{R}$ Core Team 2014) using the optim function with maxit equal to 5000 , since convergence did not occur in the first 500 iterations.

\section{RESUlTS}

Hymenoptera, Arachnida, and Coleoptera comprised $>90 \%$ of the individuals captured. Sampling resulted in a total of 92 species and 12,130 individuals (Table 3) collected from these 3 arthropod groups (see all data at https://doi.org/10.5066/F7154FH8). Hymenoptera included 22 species of ants $(n=8100)$ and a mutillid wasp $(n=233)$. Arachnida included spiders, scorpions, and pseudoscorpions. Araneae comprised 32 of the 35 arachnid species and $98 \%$ of the arachnid individuals; the other 3 species consisted of a pseudoscorpion and 2 species of scorpions. Coleoptera comprised 19 species, with Tenebrionidae dominating (9 taxa and 3161 individuals). Carabidae, also within Coleoptera, included 3 species and 27 individuals, with 5 other species in the families Elateridae, Scarabaeidae, and Chrysomelidae comprising the rest $(n=438)$. The removal of singleton species reduced the species count to 72 and the individual count to 12,110 . The subset of taxa used in the analysis is highlighted in gray in Table 3. Zone associations and feeding guilds for all taxa are identified in Table 3. Indicator species for either zone with $P \leq 0.05$ are indicated with an asterisk (Table 3). Both riparian zones had exclusively associated species (Table 3). Carabid beetles and a single spider species, Steatoda americana Emerton, were associated with the LRZ. Two ant species, Dorymyrmex insanus Buckley and Pogonomyrmex maricopa Wheeler, and a beetle, Metachroma texanum Schaeffer, were only found in pitfall traps from the URZ.

Species Richness, Total Arthropod Abundance, and Abundance of Various Groups

Based on comparison of AIC values between null and zone models, we found that species richness, overall arthropod abundance, abundances in taxonomic groups, and abundance in 2 out of 3 feeding guilds all varied significantly between lower and upper riparian zones (Table 4). Species richness, total abundance, abundance of beetles and ants, and abundance of omnivores and detritivores were all higher in upper riparian zone sites (Fig. 4). Arachnids were more common in the lower riparian zone, and predators did not vary significantly between upper and lower riparian zones (Fig. 4). The GLMM models attributed much higher variation to individual pitfall traps within study sites than to individual study sites or even different months of sampling, indicating high heterogeneity at fine spatial scales (Table 4).

\section{Proportions of Different Feeding Guilds and \\ Taxonomic Groups in Different Habitats}

The proportions of different feeding guilds and taxonomic groups also differed markedly between the habitats. A model that allowed for different proportions of different guilds in different zones had a much lower AIC (42) than a model that assumed equivalent proportions in different zones (478). Similarly, a model that allowed for different proportions of different taxonomic groups had a much lower AIC (42) than a model that assumed equivalent proportions of taxonomic groups in different zones (598). The insect community in the URZ had proportionately more omnivores and Hymenoptera (Formicidae) than in the LRZ (Fig. 5).

\section{Discussion}

Divergent arthropod communities exist in the 2 riparian zones we investigated. The URZ 
TABLE 3. List of arthropods and associated riparian habitats $(\mathrm{LRZ}=$ lower riparian zone, $\mathrm{URZ}=$ upper riparian zone; $\mathrm{X}=$ present, $-=$ absent $)$ and feeding guilds $(\mathrm{H}=$ herbivore, $\mathrm{D}=$ detritivore, $\mathrm{O}=$ omnivore, $\mathrm{P}=$ predator, $\mathrm{Pa}=$ parasite $)$. Morphospecies identified to a family are represented as the numbers $00 \mathrm{X}$ for genus and $00 \mathrm{X}$ for species. Indicator species for each zone at $P \leq 0.05$ are indicated with an asterisk. Taxa in gray are the subset used in the analysis.

\begin{tabular}{|c|c|c|c|c|c|}
\hline Order & Family & Taxon & LRZ & URZ & Feeding guild \\
\hline Coleoptera & Tenebrionidae & Eleodes extricatus Eschscholtz & $\mathrm{X}$ & $\mathrm{X}$ & $\mathrm{D} / \mathrm{S}$ \\
\hline Coleoptera & Tenebrionidae & Telabis histricum (Casey) & $\mathrm{X}$ & $\mathrm{X}$ & $\mathrm{D} / \mathrm{S}$ \\
\hline Coleoptera & Tenebrionidae & Triorophus sp. & $\mathrm{X}$ & $\mathrm{X}$ & $\mathrm{D} / \mathrm{S}$ \\
\hline Coleoptera & Tenebrionidae & Bothrotes sp. & $\mathrm{X}$ & $\mathrm{X}$ & $\mathrm{D} / \mathrm{S}$ \\
\hline Coleoptera & Tenebrionidae & Metoponium convexicolle Le-Conte & $\mathrm{X}$ & $\mathrm{X}$ & $\mathrm{D} / \mathrm{S}$ \\
\hline Coleoptera & Tenebrionidae & 003001 & - & $\mathrm{X}$ & $\mathrm{D} / \mathrm{S}$ \\
\hline Coleoptera & Tenebrionidae & 004001 & $\mathrm{X}$ & $\mathrm{X}$ & $\mathrm{D} / \mathrm{S}$ \\
\hline Coleoptera & Tenebrionidae & 005001 & $\mathrm{X}$ & $\mathrm{X}^{*}$ & $\mathrm{D} / \mathrm{S}$ \\
\hline Coleoptera & Tenebrionidae & Stenomorpha sp. & $\mathrm{X}$ & - & $\mathrm{D} / \mathrm{S}$ \\
\hline Coleoptera & Tenebrionidae & 007001 & $\mathrm{X}$ & - & $\mathrm{D} / \mathrm{S}$ \\
\hline Coleoptera & Tenebrionidae & Blapstinus brevicollis LeConte & $\mathrm{X}$ & $\mathrm{X}^{*}$ & $\mathrm{D} / \mathrm{S}$ \\
\hline Coleoptera & Elateridae & Melanotus cribicolis Leach & $\mathrm{X}$ & $\mathrm{X}$ & $\mathrm{H}$ \\
\hline Coleoptera & Elateridae & Melanotus sp. & $\mathrm{X}$ & $\mathrm{X}$ & $\mathrm{H}$ \\
\hline Coleoptera & Elateridae & Lanelater sp. 1 & $\mathrm{X}$ & $\mathrm{X}$ & $\mathrm{H}$ \\
\hline Coleoptera & Elateridae & Lanelater sp. 2 & $\mathrm{X}$ & $\mathrm{X}$ & $\mathrm{H}$ \\
\hline Coleoptera & Elateridae & Aeolus sp. & $\mathrm{X}$ & - & $\mathrm{H}$ \\
\hline Coleoptera & Scarabaeidae & Diplotaxis sp. & $\mathrm{X}$ & - & $\mathrm{H}$ \\
\hline Coleoptera & Scarabaeidae & 001001 & - & $\mathrm{X}$ & $\mathrm{H}$ \\
\hline Coleoptera & Scarabaeidae & 002001 & $\mathrm{X}$ & $\mathrm{X}$ & $\mathrm{H}$ \\
\hline Coleoptera & Scarabaeidae & 004001 & - & $\mathrm{X}$ & $\mathrm{H}$ \\
\hline Coleoptera & Scarabaeidae & 005001 & - & $\mathrm{X}$ & $\mathrm{H}$ \\
\hline Coleoptera & Chrysomelidae & Metachroma texamum Schaeffer & - & $\mathrm{X}^{*}$ & $\mathrm{H}$ \\
\hline Coleoptera & Carabidae & 001001 & $\mathrm{X}^{*}$ & $\mathrm{X}$ & $\mathrm{P}$ \\
\hline Coleoptera & Carabidae & 001002 & $X^{*}$ & - & $\mathrm{P}$ \\
\hline Coleoptera & Carabidae & 003001 & - & $\mathrm{X}$ & $\mathrm{P}$ \\
\hline Coleoptera & Carabidae & 004001 & - & $\mathrm{X}$ & $\mathrm{P}$ \\
\hline Coleoptera & Carabidae & Cicindela sp. & $\mathrm{X}$ & - & $\mathrm{P}$ \\
\hline Coleoptera & Cantharidae & 001001 & - & $\mathrm{X}$ & $\mathrm{O}(\mathrm{H} \mathrm{P})$ \\
\hline Coleoptera & Ptinidae & Niptus sp. & - & $\mathrm{X}$ & $\mathrm{H}$ \\
\hline Hymenoptera & Formicidae & Camponotus vicinus Mayr & $\mathrm{X}$ & $\mathrm{X}^{*}$ & $\mathrm{O}$ \\
\hline Hymenoptera & Formicidae & Crematogaster depilis Wheeler, W.M. & $\mathrm{X}$ & $\mathrm{X}$ & $\mathrm{O}$ \\
\hline Hymenoptera & Formicidae & Dorymyrmex insanus Buckley & $X$ & $\mathrm{X}$ & $\mathrm{O}$ \\
\hline Hymenoptera & Formicidae & Dorymyrmex bicolor Wheeler & $X$ & $X^{*}$ & $\mathrm{O}$ \\
\hline Hymenoptera & Formicidae & Formica pergandei Emery & $\mathrm{X}$ & $\mathrm{X}$ & $\mathrm{O}$ \\
\hline Hymenoptera & Formicidae & Formica integroides Wheeler, W.M. & $\mathrm{X}$ & $\mathrm{X}$ & $\mathrm{O}$ \\
\hline Hymenoptera & Formicidae & Forelius pruinosus Roger & $\mathrm{X}$ & $\mathrm{X}$ & $\mathrm{O}$ \\
\hline Hymenoptera & Formicidae & Monomorium minimum Buckley & $\mathrm{X}$ & $\mathrm{X}$ & $\mathrm{O}$ \\
\hline Hymenoptera & Formicidae & Neivamyrmex sp. & $\mathrm{X}$ & $\mathrm{X}$ & $\mathrm{P}$ \\
\hline Hymenoptera & Formicidae & Nylanderia vividula Nylander & $\mathrm{X}$ & $\mathrm{X}$ & $\mathrm{O}$ \\
\hline Hymenoptera & Formicidae & Pheidole ceres Wheeler, W.M. & $\mathrm{X}$ & $\mathrm{X}$ & $\mathrm{O}$ \\
\hline Hymenoptera & Formicidae & Pogonomyrmex maricopa Wheeler, W.M. & $\mathrm{X}$ & $\mathrm{X}^{*}$ & $\mathrm{O}$ \\
\hline Hymenoptera & Formicidae & Pogonomyrmex nr. maricopa Wheeler, W.M. & - & $\mathrm{X}$ & $\mathrm{O}$ \\
\hline Hymenoptera & Formicidae & Pogonomyrmex occidentalis Cresson & $\mathrm{X}$ & $\mathrm{X}$ & $\mathrm{O}$ \\
\hline Hymenoptera & Formicidae & Pogonomyrmex rugosus Emery & - & $\mathrm{X}$ & $\mathrm{O}$ \\
\hline Hymenoptera & Formicidae & Myrmecocystus sp. & - & $\mathrm{X}$ & $\mathrm{O}$ \\
\hline Hymenoptera & Formicidae & Solenopsis molesta Say & $\mathrm{X}$ & $\mathrm{X}$ & $\mathrm{O}$ \\
\hline Hymenoptera & Formicidae & Myrmicina sp. & $\mathrm{X}$ & $\mathrm{X}$ & $\mathrm{O}$ \\
\hline Hymenoptera & Formicidae & Pheidole sp. & $\mathrm{X}$ & $\mathrm{X}$ & $\mathrm{O}$ \\
\hline Hymenoptera & Formicidae & 001001 & - & $\mathrm{X}$ & $\mathrm{O}$ \\
\hline Hymenoptera & Formicidae & 002001 & - & $\mathrm{X}$ & $\mathrm{O}$ \\
\hline Hymenoptera & Formicidae & 003001 & $\mathrm{X}$ & $\mathrm{X}$ & $\mathrm{O}$ \\
\hline Hymenoptera & Mutillidae & Pseudomethoca sp. & $\mathrm{X}$ & $\mathrm{X}$ & $\mathrm{Pa}$ \\
\hline Araneae & Araneidae & 001001 & $\mathrm{X}$ & $\mathrm{X}$ & $\mathrm{P}$ \\
\hline Araneae & Corinnidae & Castianeira sp. & $\mathrm{X}$ & $\mathrm{X}$ & $\mathrm{P}$ \\
\hline Araneae & Corinnidae & Castianeira occidens Keyserling & $\mathrm{X}$ & $\mathrm{X}$ & $\mathrm{P}$ \\
\hline Araneae & Corinnidae & Castianeira variata Gertsch & $X^{*}$ & $\mathrm{X}$ & $\mathrm{P}$ \\
\hline Araneae & Corinnidae & Trachelas mexicanus Banks & $\mathrm{X}$ & - & $\mathrm{P}$ \\
\hline Araneae & Dictynidae & Mallos pallidus Banks & $\mathrm{X}$ & $\mathrm{X}$ & $\mathrm{P}$ \\
\hline Araneae & Gnaphosidae & 001001 & $\mathrm{X}$ & $\mathrm{X}$ & $\mathrm{P}$ \\
\hline Araneae & Gnaphosidae & Cesonia gertschi Platnick \& Shadab & $\mathrm{X}^{*}$ & $\mathrm{X}$ & $\mathrm{P}$ \\
\hline
\end{tabular}


TABLE 3. Continued.

\begin{tabular}{|c|c|c|c|c|c|}
\hline Order & Family & Taxon & LRZ & URZ & Feeding guild \\
\hline Araneae & Gnaphosidae & Drassyllus sp. & $\mathrm{X}$ & $\mathrm{X}$ & $\mathrm{P}$ \\
\hline Araneae & Gnaphosidae & Drassyllus insularis Banks & $\mathrm{X}$ & $\mathrm{X}$ & $\mathrm{P}$ \\
\hline Araneae & Gnaphosidae & Drassyllus lamprus Chamberlin & $\mathrm{X}$ & $\mathrm{X}$ & $\mathrm{P}$ \\
\hline Araneae & Gnaphosidae & Micaria sp. & - & $\mathrm{X}$ & $\mathrm{P}$ \\
\hline Araneae & Gnaphosidae & Micaria pasadena Platnick \& Shadab & $\mathrm{X}$ & $\mathrm{X}$ & $\mathrm{P}$ \\
\hline Araneae & Gnaphosidae & Nodocion eclecticus Chamberlin & $\mathrm{X}$ & $\mathrm{X}$ & $\mathrm{P}$ \\
\hline Araneae & Gnaphosidae & Nodocion utus Chamberlin & $\mathrm{X}$ & $\mathrm{X}$ & $\mathrm{P}$ \\
\hline Araneae & Gnaphosidae & Zelotes laetus O. Pickard-Cambridge & $\mathrm{X}$ & $\mathrm{X}$ & $\mathrm{P}$ \\
\hline Araneae & Linyphiidae & 001001 & $\mathrm{X}$ & - & $\mathrm{P}$ \\
\hline Araneae & Liocranidae & Neoanagraphis chamberlini Gertsch \& Mulaik & - & $\mathrm{X}$ & $\mathrm{P}$ \\
\hline Araneae & Lycosidae & 001001 & $\mathrm{X}^{*}$ & $\mathrm{X}$ & $\mathrm{P}$ \\
\hline Araneae & Lycosidae & 002001 & - & $\mathrm{X}$ & $\mathrm{P}$ \\
\hline Araneae & Lycosidae & Arctosa littoralis Hentz & $\mathrm{X}$ & - & $\mathrm{P}$ \\
\hline Araneae & Lycosidae & Camptocosa parallela Banks & $\mathrm{X}^{*}$ & $\mathrm{X}$ & $\mathrm{P}$ \\
\hline Araneae & Lycosidae & Varacosa gosiuta Chamberlin & $\mathrm{X}^{*}$ & $\mathrm{X}$ & $\mathrm{P}$ \\
\hline Araneae & Mimetidae & Mimetus hesperus Chamberlin & - & $\mathrm{X}$ & $\mathrm{P}$ \\
\hline Araneae & Oonopidae & Escaphiella hespera Chamberlin & $\mathrm{X}$ & $\mathrm{X}$ & $\mathrm{P}$ \\
\hline Araneae & Pholcidae & Psilochorus utahensis Chamberlin & $\mathrm{X}$ & $\mathrm{X}$ & $\mathrm{P}$ \\
\hline Araneae & Salticidae & 001001 & $\mathrm{X}$ & $\mathrm{X}^{*}$ & $\mathrm{P}$ \\
\hline Araneae & Salticidae & Habronattus icenoglei Griswold & $\mathrm{X}$ & $\mathrm{X}$ & $\mathrm{P}$ \\
\hline Araneae & Salticidae & Sitticus dorsatus (Banks) & $\mathrm{X}$ & $\mathrm{X}$ & $\mathrm{P}$ \\
\hline Araneae & Tetragnathidae & Tetragnatha laboriosa Hentz & - & $\mathrm{X}$ & $\mathrm{P}$ \\
\hline Araneae & Theridiidae & 001001 & $\mathrm{X}$ & - & $\mathrm{P}$ \\
\hline Araneae & Theridiidae & Latrodectus hesperus Walckenaer & $\mathrm{X}$ & $\mathrm{X}$ & $\mathrm{P}$ \\
\hline Araneae & Theridiidae & Steatoda americana Emerton & $\mathrm{X}$ & - & $\mathrm{P}$ \\
\hline Araneae & Theridiidae & Steatoda fulva Keyserling & - & $\mathrm{X}$ & $\mathrm{P}$ \\
\hline Araneae & Thomisidae & Xysticus sp. & $\mathrm{X}$ & $\mathrm{X}$ & $\mathrm{P}$ \\
\hline Pseudoscorpiones & & 001001 & $\mathrm{X}$ & $\mathrm{X}$ & $\mathrm{P}$ \\
\hline Scorpiones & Buthidae & Centruroides exilicauda Wood & $\mathrm{X}$ & - & $\mathrm{P}$ \\
\hline Scorpiones & Vaejovidae & Serradigitus sp. & $\mathrm{X}$ & $\mathrm{X}$ & $\mathrm{P}$ \\
\hline
\end{tabular}

TABLE 4. Models that included habitat zone did a better job of explaining patterns in total species richness, total abundance, and abundance of common subgroups. A substantial amount of unexplained variance was attributed to traps, as opposed to sites or dates of sampling. NA = not applicable.

\begin{tabular}{|c|c|c|c|c|}
\hline \multirow[b]{2}{*}{ Response variable } & \multirow{2}{*}{$\begin{array}{c}\text { Improvement in AIC } \\
\text { by including habitat zone }\end{array}$} & \multicolumn{3}{|c|}{ Variance of random effects } \\
\hline & & Date & Site & Trap \\
\hline Total taxonomic richness & 8 & 0 & 0.03 & 0.10 \\
\hline Total abundance & 18 & 0.35 & 0.27 & 0.54 \\
\hline \multicolumn{5}{|c|}{ ABUNDANCE BY FEEDING GUILDS } \\
\hline Detritivores/herbivores & 7 & 0.12 & 0.62 & 0.75 \\
\hline Omnivores & 20 & 0.55 & 0.52 & 0.80 \\
\hline Predators/parasites & NA & 0.23 & 0.13 & 0.71 \\
\hline \multicolumn{5}{|c|}{ ABUNDANCE BY TAXONOMIC GROUPS } \\
\hline Coleoptera only & 6 & 0.12 & 0.62 & 0.75 \\
\hline Hymenoptera only & 21 & 0.50 & 0.44 & 0.75 \\
\hline Arachnida only & 6 & 0.27 & 0.35 & 0.63 \\
\hline
\end{tabular}

is a relict habitat, having been disconnected from the river channel by river regulation over 50 years ago (Grams et al. 2007). This relict riparian habitat has low plant cover and productivity but retains high arthropod species richness and abundance compared with the LRZ (Fig. 4). The LRZ subject to river regulation, became established 50 years ago and is still subject to periodic flood disturbance and has greater cover and high productivity values (Fig. 2, Table 2) (Kennedy and Ralston 2012, Mortenson et al. 2012, Sankey et al. 2015). These results for ground-dwelling arthropods mirror patterns found by Yard et al. (2004) for the plant-dwelling arthropods along the Colorado River; they found significantly lower species richness in the LRZ compared with the URZ. The tamarisk-dominated vegetation 

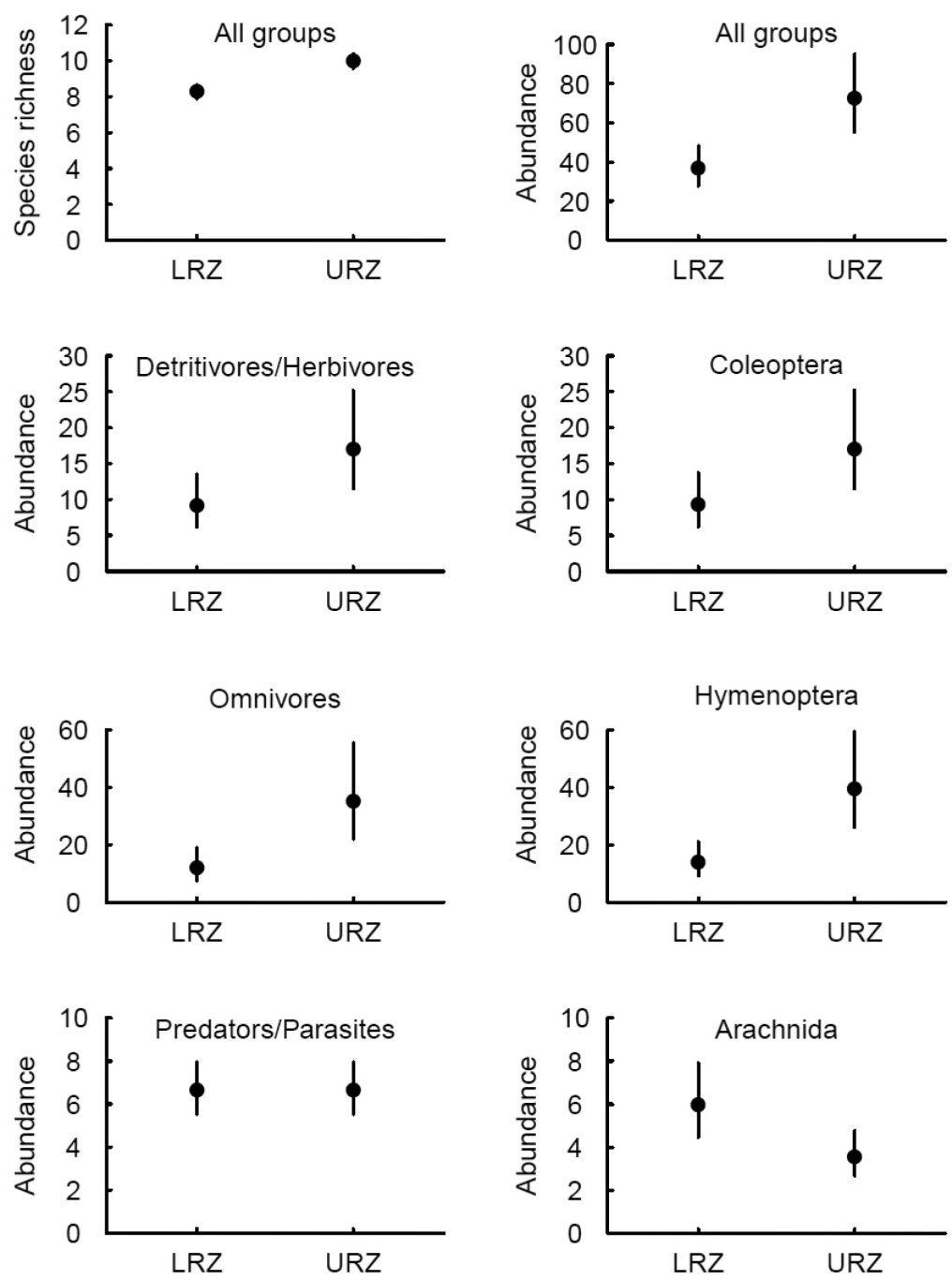

Fig. 4. Estimates of total species richness, total abundance, and abundance of common taxonomic groups and feeding guilds varied between the lower riparian zone (LRZ) and the upper riparian zone (URZ), with the exception of the predator feeding guild, which did not vary significantly. Error bars represent one standard error around the mean.

in the LRZ was associated with lower arthropod richness and lower abundance, except for Diptera and Homoptera (Yard et al. 2004). Collectively, the arthropod species richness difference observed between the URZ and LRZ supports previous observations relating arthropod richness and plant species richness (Strong et al. 1984, Siemann et al. 1998, Gerber et al. 2008).

The differences in the proportion of feeding guilds also suggest that arthropod assemblages responded to attributes of the physical environment and plant assemblages of each zone. Omnivores were the most common group between zones, and their abundance became proportionately greater as estimated productivity values and plant cover declined. They were the dominant feeding guild found in the URZ (Fig. 5). Both predators and detritivores were most abundant in the LRZ (Fig. 5). The mesic characteristic of the LRZ supports the greatest production values (Table 2) and greater litter volumes, which likely support these feeding guilds. Supplemental aquatic food resources, such as emerging Chironomidae and Simuliidae, may also support the greater proportion of predators (especially spiders) and detritivores found in the LRZ (Baxter et al. 2005, Cross et 

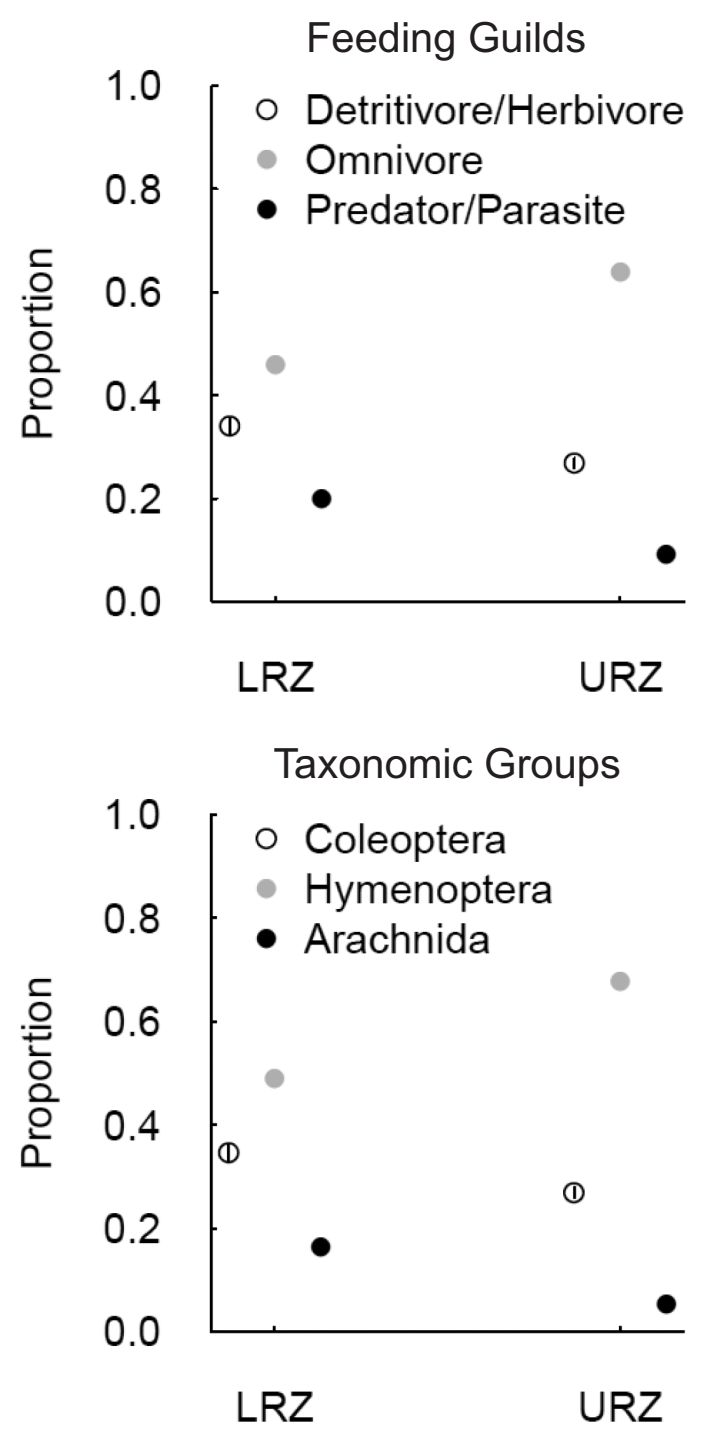

Fig. 5. Proportion of different feeding guilds (open circles $=$ detritivore/herbivore, gray circles $=$ omnivore, black circles $=$ predator) and taxonomic groups (open circles $=$ Coleoptera, gray circles $=$ Hymenoptera, black circles $=$ Arachnida) in the lower riparian zone (LRZ) and upper riparian zone (URZ). Error bars represent 95\% confidence intervals. In most cases, the confidence intervals are small and do not exceed the boundaries of the symbol for each feeding guild or taxonomic group (i.e., the lines in the open circles are the confidence intervals).

al. 2013). Our findings support those of Sanzone et al. (2003) and McCluney and Sabo (2012), who found increased richness and abundance of spiders within the active stream channel compared to the more xeric riparian habitats they sampled along Sycamore Creek and the San Pedro River in Arizona.
The LRZ supports a low-diversity arthropod community, which may nonetheless slightly increase landscape arthropod diversity. Historically, the shoreline along the Colorado River prior to regulation was bare of vegetation or in an early successional stage (Clover and Jotter 1944, Howard and Dolan 1981). Though not documented, the diversity and abundance of arthropods that occupied the predominantly bare, sandy shoreline, subject to annual flooding and reworking, are potentially lower than the results presented here, if plant structure and diversity are indicators of arthropod diversity and abundance. The LRZ dominated by nonnative tamarisk has higher production values than either the URZ, or likely, the predam, bare-sand LRZ (Kennedy and Ralston 2012), but the increased nonnative plant species associated with river regulation may limit arthropod species richness (Herrera and Dudley 2003, Gerber et al. 2008, Litt et al. 2014). In this case, river regulation may create habitats that support species of spiders and carabid beetles, but few other species that are exclusive to this zone. The combined richness found in both zones suggests a small increase in total richness for the Glen Canyon reach of the Colorado River. River regulation increases habitable space for arthropods and increases overall functional diversity, but only while the relict URZ persists. It is possible that the URZ represents an extinction debt that will not be paid for decades or centuries and which will ultimately lead to a decline in landscape diversity following regulation (Tilman et al. 1994, Kuussaari et al. 2009).

Over the timescales of years to decades, we expect that multiple factors (e.g., biocontrol agents, river regulation, and climate change) will likely continue to alter the patterns we observed in the 2 riparian zones. The arrival of the tamarisk leaf beetle (Diorhabda carinulata) in Grand Canyon in 2009 (M. Johnson personal communication) with its defoliation impacts on tamarisk (Dennison et al. 2009) may significantly alter arthropod community structure in the LRZ by affecting cover, local humidity, and soil moisture (McCluney and Sabo 2012, Sankey et al. 2016). Carabid beetle abundance may decline as habitats dry, but if spiders found in the LRZ derive a large amount of food resources from aquatic invertebrates, their abundance may be regulated 
more by aquatic production than terrestrial production (Sanzone et al. 2003, Baxter et al. 2005). The lack of large-magnitude flood disturbance contributes to the senescence and lack of recruitment of plants in the URZ (Anderson and Ruffner 1987), further affecting arthropod community structure in this drier habitat. It remains to be determined whether the dominant vegetation in the upper zone mediates ground-dwelling arthropod abundance and diversity as opposed to soil, topography, or other nonplant factors. If the dominant vegetation influences arthropod abundance and diversity and these plant species are migrating into the LRZ, then arthropods identified in the URZ can be used as indicators of drying that may take place in the LRZ. Lastly, extended drought and increased temperatures predicted for the Colorado River Basin (Seager et al. 2007, 2012) may also contribute to changes in the arthropod community observed in both zones.

\section{ACKNOWLEDGMENTS}

This work was funded by the Glen Canyon Dam Adaptive Management Program. None of the authors have any conflicts of interest, financial or otherwise, in association with this article. The Grand Canyon Monitoring and Research Center (USGS) and Humphrey Summit Support provided logistic support. Tim Andrews is thanked for the study site map. Review and discussion with Diana Kimberling, Ted Kennedy, Joanna Kraus, and 2 anonymous reviewers improved this manuscript. Any use of trade, product, or firm names is for descriptive purposes only and does not imply endorsement by the U.S. Government. Data are available at https://doi .org/10.5066/F7154FH8

\section{Literature Cited}

Anderson, L.S., and G.A. Ruffner. 1987. Effects of the post-Glen Canyon Dam flow regime on the old high water line plant community along the Colorado River in Grand Canyon. Submitted to Bureau of Reclamation, Glen Canyon Environmental Studies, National Park Service, Grand Canyon National Park, Grand Canyon, AZ.

Bagstad, K.J., S.J. Lite, and J.C. Stromberg. 2006. Vegetation, soils, and hydrogeomorphology of riparian patch types of a dryland river. Western North American Naturalist 66:23-44.

BaXter, C.V., K.D. Fausch, and W.C. Saunders. 2005. Tangled webs: reciprocal flows of invertebrate prey link streams and riparian zones. Freshwater Biology 50:201-220.

Birkin, A.S., And D.J. CoOper. 2006. Processes of Tamarix invasion and floodplain development along the lower Green River, Utah. Ecological Applications 16:1103-1120.

Bolker, B.M., M.E. Brooks, C.J. Clark, S.W. Geange, J.R. Poulsen, M.H.H. Stevens, and J.-S.S. White. 2009. Generalized linear mixed models: a practical guide for ecology and evolution. Trends in Ecology and Evolution 24:127-135.

Carothers, S.W., and B.T. Brown. 1991. The Colorado River through Grand Canyon: natural history and human change. University of Arizona Press, Tucson.

Clover, E.U., AND L. JotTer. 1944. Floristic studies in the canyon of the Colorado and tributaries. American Midland Naturalist 32:591-642.

Cross, W.F., C.V. BaXter, E.J. Rosi-Marshall, R.O. Hall Jr., T.A. Kennedy, K.C. Donner, H.A. Wellard Kelly, S.E.Z. Seegert, K. Behn, and M.D. Yard. 2013. Food-web dynamics in a large river discontinuum. Ecological Monographs 83:311-337.

DAvis, P.A. 2013. Natural-color and color-infrared image mosaics of the Colorado River corridor in Arizona derived from the May 2009 airborne image collection. U.S. Geological Survey Data Series 780.

Dennison, P.E., P.L. Nagler, K.R. Hultine, E.P. Glenn, AND J.R. EHLERINGER. 2009. Remote monitoring of tamarisk defoliation and evapotranspiration following saltcedar leaf beetle attack. Remote Sensing of Environment 113:1462-1472

DigweED, S.C. 1995. Digging out the "digging-in effect" of pitfall traps: influences of depletion and disturbance on catches of ground beetles (Coleoptera: Carabidae). Pedobiologia 39:561-576.

Dufrêne, M., AND P. Legendre. 1997. Species assemblages and indicator species: the need for a flexible asymmetric approach. Ecological Monographs 67: 345-366.

Durst, S.L., T.C. Theimer, E.H. Paxton, and M.K. SogGE. 2008. Temporal variation in the arthropod community of desert riparian habitats with varying amounts of saltcedar (Tamarix ramosissima). Journal of Arid Environments 72:1644-1653.

Ellis, L.M., M.C. Molles, C.S. Crawford, and F. Heinzelmann. 2000. Surface-active arthropod communities in native and exotic riparian vegetation in the Middle Rio Grande Valley, New Mexico. Southwestern Naturalist 45:456-471.

[ESRI] Environmental Systems Research Institute. 2013. ArcGIS for Desktop, version 10.2. Esri, Redlands, CA.

Friedman, J.M., G.T. Auble, P.B. Shafroth, J.M. Scott, M.F. Merigliano, M.D. Freehling, and E.R. GrifFIN. 2005. Dominance of non-native riparian trees in western USA. Biological Invasions 7:747-751.

Gerber, E., C. Krebs, C. Murrell, M. Moretti, R. Rocklin, and U. Schaffner. 2008. Exotic invasive knotweeds (Fallopia spp.) negatively affect native plant and invertebrate assemblages in European riparian habitats. Biological Conservation 141: 646-654.

GILlespie, R.G., AND G.K. Roderick. 2002. Arthropods on islands: colonization, speciation, and conservation. Annual Review of Entomology 47:595-632.

Grams, P.E., J.C. SchmidT, AND D.J. Topping. 2007. The rate and pattern of bed incision and bank adjustment 
on the Colorado River in Glen Canyon downstream from Glen Canyon Dam, 1956-2000. Geological Society of America Bulletin 119:556-575.

Grams, P.E., J.C. Schmidt, S.A. Wright, D.J. Topping, T.S. MeLis, and D.M. Rubin. 2015. Building sandbars in the Grand Canyon. Eos 96:12-16.

Greenwood, H., D.J. O'Dowd, and P.S. LaKe. 2004. Willow (Salix $\times$ rubens $)$ invasion of the riparian zone in south-eastern Australia: reduced abundance and altered composition of terrestrial arthropods. Diversity and Distributions 10:485-492.

HARDEN, D.R. 1990. Controlling factors in the distribution and development of incised meanders in the central Colorado Plateau. Geological Society of America Bulletin 102:233-242.

Hazel, J.E., Jr., D.J. Topping, J.C. Schmidt, And M. KAPLINSKI. 2006. Influence of a dam on fine-sediment storage in a canyon river. Journal of Geophysical Research-Earth Surface 111:1-16.

Hereford, R., K.J. Burke, and K.S. Thompson. 2000. Map showing Quaternary geology and geomorphology of the Lees Ferry area, Glen Canyon, Arizona. U.S. Geological Survey, Geologic Investigations Series I-2663. 4 pp.

Herrera, A.M., and T.L. Dudley. 2003. Reduction of riparian arthropod abundance and diversity as a consequence of giant reed (Arundo donax) invasion. Biological Invasions 5:167-177.

Higgins, J.W., N.S. Cobb, S. Sommer, R.J. Delph, and S.L. Brantley. 2014. Ground-dwelling arthropod responses to succession in a pinyon-juniper woodland. Ecosphere 5:1-29.

Howard, A.D., AND R. Dolan. 1981. Geomorphology of the Colorado River in Grand Canyon. Journal of Geology 89:269-298.

Johnson, W.C. 2002. Riparian vegetation diversity along regulated rivers: contribution of novel and relict habitats. Freshwater Biology 47:749-759.

Kearsley, M.J.C., And T.J. Ayers. 1999. Riparian vegetation responses: snatching defeat from the jaws of victory and vice versa. Pages 309-327 in R.H. Webb, J.C. Schmidt, G.R. Marzolf, and R.A. Valdez, editors, The controlled flood in Grand Canyon. Geophysical Monograph Series, Volume 110. American Geophysical Union, Washington, DC.

Kennedy, T.A., And B.E. Ralston. 2012. Regulation leads to increases in riparian vegetation, but not direct allochthonous inputs, along the Colorado River in Grand Canyon, Arizona. River Research and Applications 28:2-12.

Kennedy, T.A., C.B. Yackulic, W.F. Cross, P.E. Grams, M.D. YARD, AND A.J. COPP. 2014. The relation between invertebrate drift and two primary controls, discharge and benthic densities, in a large regulated river. Freshwater Biology 59:557-572.

Knopf, F.L., R.R. Johnson, T. Rich, F.B. SAmson, and R.C. SZARO. 1988. Conservation of riparian ecosystems in the United States. Wilson Bulletin 100:272-284.

Kuussaari, M., R. Bommarco, R.K. Heikkinen, A. Helm, J. Krauss, R. Lindborg, E. Öckinger, M. PÄrtel, J. PINO, F. RODÀ, ET AL. 2009. Extinction debt: a challenge for biodiversity conservation. Trends in Ecology and Evolution 24:564-571.

Larochelle, A., AND M.C. LaRivière. 2003. Natural history of the ground-beetles (Coleoptera: Carabidae) of America north of Mexico. Pensoft Publishers, Sofia, Bulgaria.
LEATHER, S.R. 2005. Sampling theory and practice. Blackwell Publishing, Oxford, United Kingdom.

LitT, A.R., E.E. Cord, T.E. Fulbright, and G.L. SchusTER. 2014. Effects of invasive plants on arthropods. Conservation Biology 28:1532-1549.

Maceda-Veiga, A., H. Basas, G. Lanzaco, M. Sala, A. DE SostoA, AND A. SERRA. 2016. Impacts of the invader giant reed (Arundo donax) on riparian habitats and ground arthropod communities. Biological Invasions 18:731-749.

McClunEy, K.E., AND J.L. SABo. 2012. River drying lowers the diversity and alters the composition of an assemblage of desert riparian arthropods. Freshwater Biology 57:91-103.

McCune, B., and M.J. Mefford. 1999. Multivariate analysis of ecological data, PC-ORD, vers. 6.08. MjM Software Design, Gleneden Beach, OR.

Mortenson, S.G., P.J. Weisberg, and L.E. Stevens. 2012. The influence of floods and precipitation on Tamarix establishment in Grand Canyon, Arizona: consequences for flow regime restoration. Biological Invasions 14:1061-1076.

Nguyen, K.Q., P. Cuneo, S.A. Cunningham, D.W. Krix, A. Leigh, AND B.R. Murray. 2016. Ecological effects of increasing time since invasion by the exotic African olive (Olea europaea ssp. cuspidata) on leaf-litter invertebrate assemblages. Biological Invasions 18:1689-1699.

Perner, J., C. Wytrykush, A. Kahmen, N. Buchmann, I. Egerer, S. Creutzburg, N. Odat, V. Audorff, and W.W. WEISSER. 2005. Effects of plant diversity, plant productivity and habitat parameters on arthropod abundance in montane European grasslands. Ecography $28: 429-442$.

Porras-Alfaro, A., J. Herrera, D.O. Natvig, K. Lipinski, and R.L. Sinsabaugh. 2011. Diversity and distribution of soil fungal communities in a semiarid grassland. Mycologia 103:10-21.

R CoRe Team. 2014. A language and environment for statistical computing. R Foundation for Statistical Computing, Vienna, Austria.

Rood, S.B., J.H. Braatne, and L.A. Goater. 2009. Responses of obligate versus facultative riparian shrubs following river damming. River Research and Applications 26:102-117.

Sabo, J.L., R.A. Sponseller, M. Dixon, K. Gade, T. Harms, J. Heffernan, A. Jani, G. Katz, C. Soykan, J. Watts, AND J. Welter. 2005. Riparian zones increase regional species richness by harboring different, not more, species. Ecology 86:56-62.

Sankey, J.B., B.E. Ralston, P.E. Grams, J.C. Schmidt, and L.E. CAGNey. 2015. Riparian vegetation, Colorado River, and climate: five decades of spatiotemporal dynamics in the Grand Canyon with river regulation. Journal of Geophysical Research: Biogeosciences 120:1532-1547.

Sankey, T.T., J.B. Sankey, R. Horne, and A. Bedford. 2016. Remote sensing of tamarisk biomass, insect herbivory, and defoliation: novel methods in the Grand Canyon Region, Arizona. Photogrammetric Engineering and Remote Sensing 82:645-652.

Sanzone, D.M., J.L. Meyer, E. Marti, E.P. Gardiner, J.L. TANK, AND N.B. GRIMM. 2003. Carbon and nitrogen transfer from a desert stream to riparian predators. Oecologia 134:238-250.

Schaffers, A.P., I.P. RaEmaKers, K.V. SÝKORA, and C.J.F. ter Braak. 2008. Arthropod assemblages are best 
predicted by plant species composition. Ecology 89:782-794.

Schmidt, J.C., AND P.E. Grams. 2011. Understanding physical processes of the Colorado River, in effects of three high-flow experiments on the Colorado River ecosystem downstream from Glen Canyon Dam, Arizona. Pages 17-51 and 53-91 in T.S. Melis, editor, U.S. Geological Survey Circular 1366. http:// pubs.usgs.gov/circ/1366/c1366.pdf

Seager, R., M. Ting, I. Held, Y. Kushnir, J. Lu, G. Vecchi, H.-P. Huang, N. Harnick, A. Leetmaa, N.-C. Lua, C. Li, J. Velez, and N. Naik. 2007. Model projections of an imminent transition to a more arid climate in southwestern North America. Science 316:1181-1184.

Seager, R., M. Ting, C. Li, N. Naik, B. CoOK, J. NaKaMURA, AND H. LIU. 2012. Projections of declining surface-water availability for the southwestern United States. Nature Climate Change 3:482-486.

Siemann, E. 1998. Experimental tests of effects of plant productivity and diversity on grassland arthropod diversity Ecology 79:2057-2070.

Siemann, E., D. Tilman, J. Haarstad, and M. Ritchie. 1998. Experimental tests of the dependence of arthropod diversity on plant diversity. American Naturalist 152:738-750.

Stevens, L.E., J.C. Schmidt, T.J. Ayers, and B.T. Brown. 1995. Flow regulation, geomorphology, and Colorado River marsh development in the Grand Canyon, Arizona. Ecological Applications 5:1025-1039.

StromberG, J.C. 2001. Influence of stream flow regime and temperature on growth rate of the riparian tree, Platanus wrightii, in Arizona. Freshwater Biology 46:227-239.

Stromberg, J.C., D.T. Patten, and B.D. Richter. 1991. Flood flows and dynamics of Sonoran riparian forests. Rivers 2:221-235.

Strong, D.R., J.H. LAWTON, AND S.R. Southwood. 1984 Insects on plants: community patterns and mechanisms. Blackwell Scientific Publications.

Tilman, D., R.M. May, C.L. Lehman, and M.A. NowaK. 1994. Habitat destruction and the extinction debt. Nature 371:65-66.

Topp, W., H. Kappes, and F. Rogers. 2008. Response of ground-dwelling beetle (Coleoptera) assemblages to giant knotweed (Reynoutria spp.) invasion. Biological Invasions 10:381-390.

Topping, D.J., D.M. Rubin, And J.C. Schmidt. 2005. Regulation of sand transport in the Colorado River by changes in the surface grain size of eddy sandbars over multi-year timescales. Sedimentology 52:1133-1153.

Topping, D.J., D.M. Rubin, and L.E. Vierra JR. 2000. Colorado River sediment transport: 1. Natural sediment supply limitation and the influence of the Glen Canyon Dam. Water Resources Research 36: 515-542.

Topping, D.J., J.C. Schmidt, and L.E. Vierra. 2003. Computation and analysis of the instantaneous-discharge record for the Colorado River at Lees Ferry, Arizona: May 8, 1921, through September 30, 2000. U.S. Geological Survey Professional Paper 1677.

Triplehorn, C.A., AND N.F. Johnson. 2005. Borror and Delong's introduction to the study of insects. 7th edition. Thompson Brooks/Cole, Belmont, CA.

Turner, R.M., AND M.M. KarPisCAK. 1980. Recent vegetation changes along the Colorado River between Glen Canyon Dam and Lake Mead, Arizona. U.S. Geological Survey Professional Paper 1132.

Tuttle, N., K. Beard, And W. Pitt. 2009. Invasive litter, not an invasive insectivore, determines invertebrate communities in Hawaiian forests. Biological Invasions 11:845-855.

[USDi] United States Department of the Interior. 1996. Record of decision, operation of Glen Canyon Dam-final environmental impact statement. Office of the Secretary of the Interior, Bureau of Reclamation, Washington, DC.

van Hengstum, T., D.A.P. Hooftman, J.G.B. OostermeiJER, AND P.H. VAN TIENDEREN. 2014. Impact of plant invasions on local arthropod communities: a metaanalysis. Journal of Ecology 102:4-11.

WebB, R.H. 1996. Grand Canyon, a century of change: rephotography of the 1889-1890 Stanton expedition. University of Arizona Press, Tucson, AZ.

Woodcock, B.A., J. Redhead, A.J. Vanbergen, L. Hulmes, S. Hulmes, J. Peyton, M. Nowakowski, R.F. PYwell, AND M.S. HEARD. 2010. Impact of habitat type and landscape structure on biomass, species richness and functional diversity of ground beetles. Agriculture, Ecosystems and Environment 139:181-186.

YaRd, H.K., C. VAN Riper III, B.T. BROWN, AND M.J. KeARSLEy. 2004. Diets of insectivorous birds along the Colorado River in Grand Canyon, Arizona. Condor 106:106-115.

Received 3 October 2016 Accepted 5 August 2017 Published online 12 October 2017 